\title{
SOME INTERESTING COLOURLESS EUGLENOPHYTES FOUND IN SOUTHERN POLAND
}

\author{
JOLANTA CABAŁA \\ Department of Phycology, W. Szafer Institute of Botany \\ Polish Academy of Sciences \\ Lubicz 46, 31-512 Cracow, Poland \\ e-mail: cabala@ib-pan.krakow.pl \\ (Received: November 6, 2002. Accepted: April 15, 2003)
}

\begin{abstract}
This study present 9 species of colourless euglenoid flagellates found in a small peat bog in Budzyń, a village north-west of Cracow, which belongs to the Małopolska Upland (Southern Poland). This threatened peat bog is covered with rubble brought from neighbouring Cracow. Only ca $30 \%$ of its area is relatively little influenced by human activity. Many of the present species are rarely and infrequently reported from nature. Three species, including Rhabdomonas incurva Fresenius, Entosiphon obliquum Klebs, E. ovatum Stokes, and one variety Menoidium pellucidum Perty var. gracile (Playfair) Popova have been recorded for the first time from Poland. Three species Astasia dangeardii Lemmermann var. dangeardii, Rhabdomonas costata (Koršikov) Pringsheim and Entosiphon sulcatum (Dujardin) Stein var. sulcatum Stein are new for the flora of Cracow-Częstochowa Upland. The remaining taxa: Menoidium pellucidum Perty var. pellucidum and M. tortuosum (Stokes) Senn var. tortuosum are very rarely recorded from Poland. For each species illustrations, taxonomic information and biogeographical data are given.
\end{abstract}

KEY WORDS: Euglenophyta, Astasia, Menoidium, Rhabdomonas, Entosiphon, taxonomy, peat bog.

\section{INTRODUCTION}

The specimens of colourless euglenophytes presented here were found on a small peat bog in Budzyń village, northwest of Cracow, which belongs to the Małopolska Upland (Southern Poland). It is the last peat bog in the CracowCzęstochowa Upland that still possesses a rich algae flora. The present study is a part of a comprehensive study on algae flora from this peat bog. The first material from this area was taken in winter 1998 by Wołowski (1998). In samples of plankton and mud under ice he found only single specimens of Euglena mutabilis, E. viridis fo. viridis, E. agilis, E. hemichromata, Trachelomonas rugulosa, several taxa of diatoms and single specimens of other algae.

The information on the occurrence of colourless euglenophytes in the Cracow-Częstochowa Upland and in Poland is random and poor. Only studies by Wołowski carried out from 1985 to 2002 fill the still incomplete evidence (Wołowski 1991a, 1991b, 1995, 1998).

\section{MATERIAL AND METHODS}

The material was collected from January to December during 1999-2001, usually once a month, in $120 \mathrm{ml}$ plastic containers. The material was collected with a manual water pump and a spoon from the water surface, beneath the surface, the bottom of the peat bog cavities and the drain ditch, or squeezed of Sphagnum spp. In laboratory three microscopic slides were prepared from each sample (120 $\mathrm{ml}$ plastic containers). The slides were carefully analyzed for detection of euglenophytes. All measurements, descriptions, drawings, photographs and observations were made from living material. For each taxon several specimens (26) were measured. Amplival Carl Zeiss Jena light microscope was used for the studies. To immobilize them, the specimens were treated with $0.5 \%$ solution of glutaraldehyde. Original drawings were made with the aid of a camera lucida, photographs were taken with a Zeiss automatic photographic system. Abundance of the species, expressed in terms of the number of its specimens, was estimated using a five degree scale (Wołowski 1998) as follows:

+- the species occurred only as a single specimen at least on one slide;

1 - the species occurred as up to 6 specimens, on almost every slide (sparse);

2 - the species occurred on every slide but not on all visible fields (frequent);

3 - the species occurred on every slide and visible field (very frequent); 
4 - the species occurred a bloom on the surface of the water, visible to the naked eye (in masses).

The data on occurrence of the taxa in Poland and in the world were taken from the Iconotheca of Algae of Department of Phycology, W. Szafer Institute of Botany, Polish Academy of Sciences in Cracow.

\section{RESULTS}

Among the relatively numerous algae, rarely reported in Poland and Europe, the following species of colourless euglenophytes were found: Astasia (1 taxon), Menoidium (3), Rhabdomonas (2), Entosiphon (3). Three species, viz., Astasia dangeardii Lemmermann var. dangeardii, Rhabdomonas costata (Koršikov) Pringsheim and Entosiphon sulcatum (Dujardin) Stein var. sulcatum Stein are new for the flora of the Cracow-Częstochowa Upland. Three other species, including Rhabdomonas incurva Fresenius, Entosiphon obliquum Klebs, E. ovatum Stokes, and one variety Menoidium pellucidum Perty var. gracile (Playfair) Popova have been recorded for the first time in Poland. They occurred singly (+) or sparsely (1), mainly in 2000 and 2001, in spring (March, April and May) and in summer (June, August), in water of $\mathrm{pH} 7.3,231.4 \mu \mathrm{S}, 64.2 \mathrm{mV}$, mainly from the bottom of the small peat bog cavities, in water squeezed of Sphagnum spp., and rarely from the water surface.

Species new to the Polish flora are marked with two asterisks (**), species new to the Cracow-Częstochowa Upland with one asterisk $(*)$.

\section{ASTASIA Dujardin 1841 \\ * Astasia dangeardii Lemmermann 1910 var. dangeardii (Figs 1-2)}

LM description: Cells lengthwise-clavate or fusiform. Anterior end is obliquely bevel, posterior end is gradually narrow. Cells 35.8-42.0 $\mu \mathrm{m}$ long, 9.0-9.5 $\mu \mathrm{m}$ wide. Found in March $2000(+)$ and April 2000 (+).

Distribution in Poland: This species was recorded from Poland by Dreżepolski (1925), but without precise locality. General distribution: Europe, Asia, and America.

Habitats: organic contaminated waters.

\section{MENOIDIUM Perty 1852}

** Menoidium pellucidum Perty var. gracile (Playfair) Popova \& Safonova 1976 (Figs 3-4)

Synonym: Menoidium gracile Playfair 1921.

LM description: Cells flattened, curved, strongly elongated. Anterior end is slightly tapered into narrow neck, often with 1-2 teeth (not well visible on the pictures), posterior end bluntly rounded. The pellicle is gently striated lengthwise, the striae occurring in the form of tiny papillae. The nucleus is slightly shifted to the posterior end of the cell or, rarely occurs in its centre. Cells 50.0-78.5 um long, 6.5-9.0 um wide. Found in April 2000 (+) and September 2001 (1).

Note: This species is distinguished from $M$. pellucidum Perty var. pellucidum on the basis of size (Starmach 1983; Wołowski 1998).

General distribution: Asia, Australia and America. Habitats: peat bogs.
Menoidium pellucidum Perty var. pellucidum (Fig. 5)

LM description: Cells flattened, curved, elongated. Anterior end is slightly tapered into narrow neck, often with 1-2 teeth (not well visible on the pictures), posterior end bluntly rounded. The pellicle is gently striated lengthwise, the striae occurring in the form of tiny papillae. The nucleus is slightly shifted to the posterior end of the cell or, rarely, occurs in its centre. The flagellum is shorter then the cell, being 1/3-1/4 of its length. Cells 41.5-53.5 $\mu \mathrm{m}$ long, 8.0$-11.5 \mu \mathrm{m}$ wide. Found in May $2000(+)$ and August $2001(+)$.

Distribution in Poland: Recorded by Dreżepolski (1948) who did not mention the site (Wołowski 1998) and in the Cracow-Częstochowa Upland (Wołowski 1991b, 1998).

General distribution: Cosmopolitan.

Habitats: Stagnant and slowly flowing waters, small water bodies, peat bogs.

Saprobity: $\alpha$-mesosaprobic (Vetrova 1980).

Menoidium tortuosum (Stokes) Senn var. tortuosum (Popova \& Safonova 1976) (Figs 6-10)

Synonyms: Atractonema tortuosa Stokes, Astasia tortuosa (Stokes) Popova 1951.

LM description: Cells are narrowly lanceolate-fusiform, falcate or twisted like an S, slightly extended and bluntly truncated at the apex, slightly tapered and bluntly extended at the posterior end. The pellicle is narrow and slightly lengthwise striated. The nucleus is slightly shifted to the posterior end of the cell. The specimens are 40.0-47.0 $\mu \mathrm{m}$ long, 5.0-8.0 $\mu \mathrm{m}$ wide. Found in May $2001(+)$.

Note: I observed live, freely swimming specimens, which had a typical S-like shape, slightly extended, as seen in description by Popova \& Safonova (1976) (Fig. 6 after Starmach: Fig. 1164: 431-432), but after immobilization the specimens changed the shape (Figs 7-10).

Distribution in Poland: Recorded in the Cracow-Czestochowa Upland in Elżbieta spring of the Wiercica stream (Wołowski 1991b, 1998), and in karstic pond in Bębło (Wołowski 1998).

General distribution: Europe, Australia, and Asia.

Habitats: peat bogs.

RHABDOMONAS Fresenius (Starmach 1983)

* Rhabdomonas costata (Koršikov) Pringsheim 1942 (Figs 11-13)

Synonyms: Menoidium costatum Koršikov 1928, M. lingum Pringsheim, M. semilunaris Wermel, M. semilunaris var. regularis Wermel.

LM description: Cells longitudinally extended, with flat or slightly convex abdominal side, the dorsal side arcuate. Pellicle with 6 steeply helical ridges. The nucleus is slightly shifted to the posterior end of the cell. Paramylon bodies of different size. Cells 22.5-26.0 $\mu \mathrm{m}$ long, 6.0-8.5 $\mu \mathrm{m}$ wide. Found in October $2001(+)$.

Distribution in Poland: In the bogs „Upa”, „Topieliska”, and Hala Izerska mountain meadow in the Sudeten Mts. (Matuła 1980), and in the lake Krzywe in the Wigry National Park (Wołowski 1991a).

General distribution: Europe, Asia, and North America.

Habitats: peat bog pool plankton, ponds.

Saprobity: $\alpha$-mesosaprobic (Vetrova 1980). 

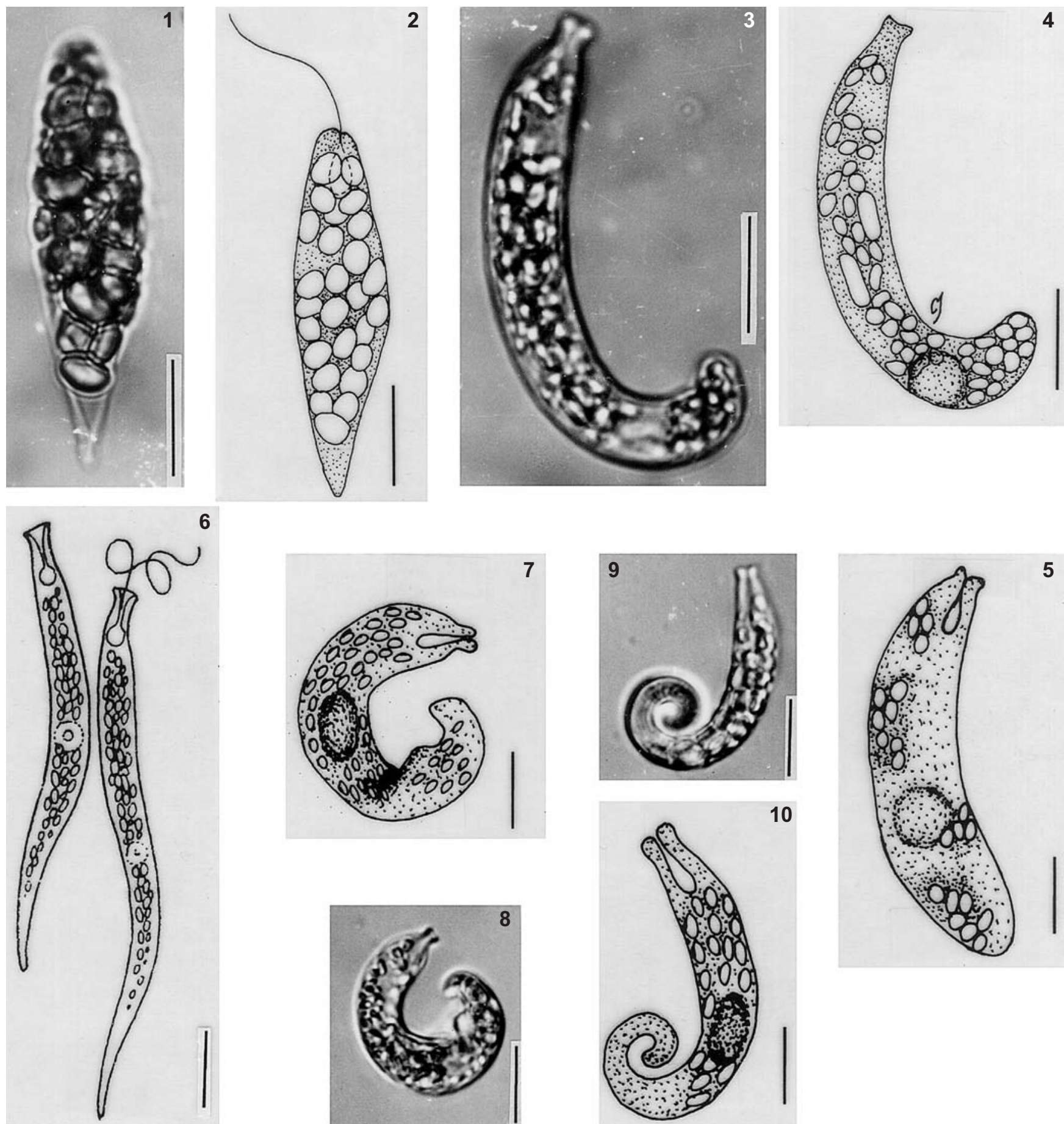

Figs 1-10. Figs 1-2. Astasia dangeardii var. dangeardii; Figs 3-4. Menoidium pellucidum var. gracile; Fig. 5. M. pellucidum var. pellucidum; Fig. 6. M. tortuosum var. tortuosum - live, freely swimming specimens (after Starmach 1983: 1164); Figs 7-10. M. tortuosum var. tortuosum - after immobilization cells changed the shape, especially at the posterior end. Scale bars $=10 \mu \mathrm{m}$.

** Rhabdomonas incurva Fresenius (Starmach 1983) (Figs 14-16)

Synonyms: Menoidium incurvum (Fresenius) Klebs 1893, Astasia proteus Stein.

LM description: Cells cylindrical, slightly curved with rounded ends. Pellicle with 6-8 steeply helical ridges. The nucleus occurs in the centre of the cell or, rarely, is slightly shifted to the posterior end. Cells $15.5-18.5 \mu \mathrm{m}$ long, 6.0$-6.5 \mu \mathrm{m}$ wide. Found in April 2000 (+) and August 2001 (+). General distribution: Cosmopolitan.

Habitats: peaty waters, particularly with decaying leaves, mud, forest puddles, ponds and stagnant waters.

Saprobity: $\alpha$-mesosaprobic (Vetrova 1980).

\section{ENTOSIPHON Stein 1878}

** Entosiphon obliquum Klebs 1893 (Figs 17-19)

LM description: Cells ovoid, convex. Anterior end oblique cut, posterior end slightly narrowed. Pellicle delicately striated. Canal opening subapical, siphon ca. $1 / 2$ of the cell length. Two unequal flagella. Cells 13.0-15.0 $\mu \mathrm{m}$ long, 6.7$-9.2 \mu \mathrm{m}$ wide. Found in December $2000(+)$.

General distribution: Cosmopolitan.

Habitats: Stagnant water, puddles, ponds, lakes.

** Entosiphon ovatum Stokes (Vetrova 1980) (Figs 20-21)

LM description: Cells ovoid, slightly flattened. Anterior end is rounded with apical depression. Pellicle ribbed. Ca- 

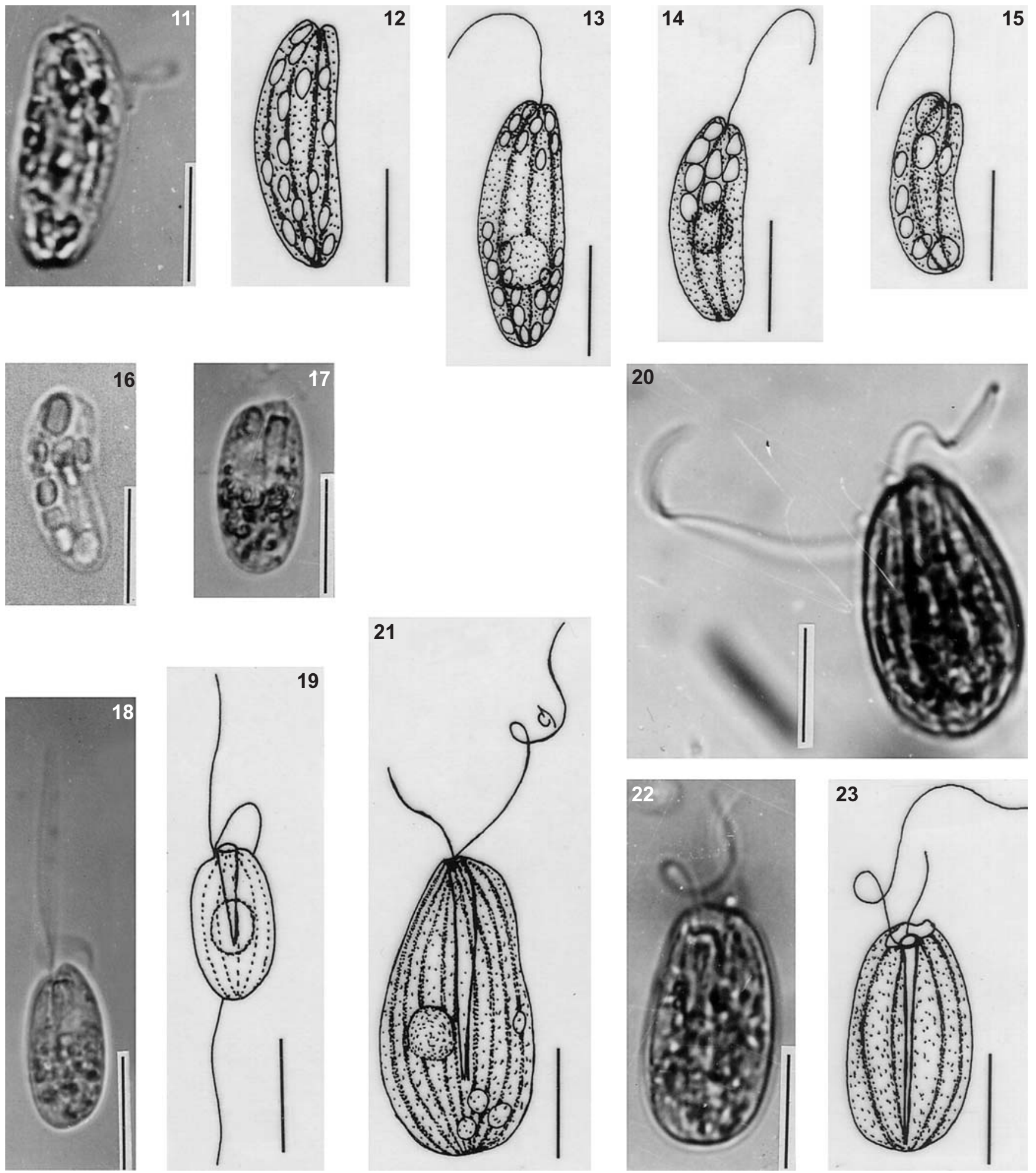

Figs 11-23. Figs 11-13. Rhabdomonas costata; Figs 14-16. R. incurva; Figs 17-19. Entosiphon obliquum; Figs 20-21. E. ovatum; Figs 22-23. E. sulcatum var. sulcatum. Scale bars $=10 \mu \mathrm{m}$.

nal opening subapical, siphon prominent, conical, $3 / 4$ of the cell length. Two unequal flagella. Cells 26.5-27.0 um long, 13.0-14.2 um wide. Found in June $2000(+)$.

General distribution: Cosmopolitan.

Habitats: Stagnant water, ponds, pools, mud.

Saprobity: $\alpha-\beta$-mesosaprobic (Vetrova 1980).
* Entosiphon sulcatum (Dujardin) Stein var. sulcatum Stein 1878 (Vetrova 1980) (Figs 22-23)

Synonyms: Anisonema sulcatum Dujardin 1841, A. entosiphon (Stein) Klebs, Heteronema sulcata Meresch.

LM description: Cells ovoid, flattened. Anterior end oblique incised with apical depression, posterior end slightly narrowed and rounded. Pellicle rigid, slightly flattened with pronounced helical ridges. Canal opening subapical, siphon conical, as long as cell. Two unequal flagella. Cells 
17.5-24.0 $\mu \mathrm{m}$ long, 10.2-12.5 $\mu \mathrm{m}$ wide. Found in September $1999(+)$ and June 2000 (1).

Distribution in Poland: In the springs „Jerzy” in Wierchomla and „Stanisław” in Łabowa in the Western Carpathians (Rajchel et al. 2002).

General distribution: Cosmopolitan.

Habitats: Stagnant and slowly flowing water, overgrown lakes, ponds, puddles, often in planktonic in ponds and lakes. Saprobity: pH 5.0-5.5 (Vetrova 1980).

\section{ACKNOWLEDGEMENTS}

I am grateful to the anonymous reviewer and to Associate Professor Konrad Wołowski for valuable taxonomic advice and very helpful detailed remarks on the manuscript. Special thanks are due to Alina Pachońska-Wołowska for polishing the English version of this work and to Marcin Piątek for his help with preparing the drawings and photographs.

This work was supported by the State Committee for Scientific Research (KBN grant 6 P04G 022 20).

\section{LITERATURE CITED}

DREŻEPOLSKI R. 1925. Przyczynek do znajomości polskich Euglenin. - Supplément a la connaissance des Euglénienes de la Pologne. Kosmos 50: 173-270. (in Polish with French summary)

DREŻEPOLSKI R. 1948. Eugleniny denne (Les eugléniens bentheaux). Mat. Fizjogr. Kraju 8: 1-18. (in Polish with French summary)

DUJARDIN F. 1841. Histoire naturelle des Zoophytes-Infusoires. 684 pp. Paris.

KLEBS G. 1893. Flagellatenstudien I, II. Z. Wiss. Zool. 55: 265-445 .

KORS̆IKOV A.A. 1928. Nekotoryje dannyje o rozpredelenii vodoroslej i žgutikovych v Licinskom Bolote. Tr. Zvenigorodsk. Gidrobiol. Stan. Inst. Exper. Biol. M. 1928. (in Russian)

LEMMERMANN E. 1910. Kryptogamenflora der Mark Brandenburg. III. Algen. 712 pp. Verlag von Gebrüder Borntrarger, Leipzig.

MATUŁA J. 1980. Algae new or rare to the Polish flora, found in peat bogs of the Sudeten Mts. Fragm. Florist. Geobot. 26 (1): 121-136.

PERTY M. 1852. Zur Kenntnis kleinster Lebensformen nach Bau. Funktionen. Systematik mit Spezialverzeichnis der in Schweiz beobachteten Arten. 228 pp. Verlag von Jent und Reinert, Bern.

PLAYFAIR G.J. 1921. Australian freshwater flagellates. Proc. Linn. Soc. New South Wales 46: 99-146.

POPOVA T.G. 1951. Euglenovyje (Euglenineae) evropejskogo Severa SSSR [Euglenineae of the European north of the Soviet Union]. Trudy Bot. Inst. Akad. Nauk SSSR, Ser. 2. Sporov. Rast. 7: 165-414. (in Russian)

POPOVA T.G., SAFONOVA T.A. 1976. Flora Sporovych Rastenij SSSR (Flora plantarum cryptogamarum URSS) 9. Euglenophyta. 2. 278 pp. Izdatelstvo Nauka, Leningrad. (in Russian)

PRINGSHEIM E.G. 1942. Contribution to our knowledge of saprotrophytic algae and Flagellata III. Astasia, Distigma, Menoidiomonas, Rhabdomonas. New Phytol. 41: 171-205.

RAJCHEL L., RAJCHEL J., WOŁOWSKI K. 2002. Microorganisms in selected sulphuric springs of the Polish Carpathians. Geological Quarterly 46 (2): 189-198.

STARMACH K. 1983. Euglenophyta - Eugleniny. Flora Słodkowodna Polski (Euglenophyta. Freshwater Flora of Poland). 3. 594 pp. Państwowe Wydawnictwo Naukowe, Warszawa-Kraków. (in Polish)

STEIN F.R. 1878. Der Organismus der Infusionsthiere. III. Der Organismus der Flagellaten, I. 154 pp. Verlag von Wilhelm Engelmann, Leipzig.

VETROVA Z.I. 1980. Bessvetnyje vodorosly Ukrainy, (Colourless euglenophytes from Ukraine). 182 pp. Izdatelstvo Naukova Dumka, Kiiv. (in Ukrainian)

WOŁOWSKI K. 1991a. Some Euglenophyta from the Wigry National Park (Suwałki lake district, Poland) In: L. Burchardt (ed.). IX Symposium Phycological Section Polish Botanical Association. International Symposium, Poznań 16-22. 05. 1990. „Evolution of freshwater lakes”. Part II]. pp. 191-206, Wydawnictwo Uniw. A. Mickiewicza, Poznań.

WOŁOWSKI K. 1991b. New and rare species of the colourless Euglenophyta in Poland. Fragm. Florist. Geobot. 36 (2): 509-514.

WOŁOWSKI K. 1995. Dylakosoma pelophilum a rare colourless euglenophyte found in Poland. Algol. Stud. 76: 75-78.

WOŁOWSKI K. 1998. Taxonomic and environmental studies on Euglenophytes of the Cracow-Częstochowa Upland (southern Poland). Fragm. Florist. Geobot., Supplement 6: 1-192.

\section{INTERESUJACE GATUNKI BEZBARWNYCH EUGLENIN Z POŁUDNIOWEJ POLSKI}

\section{STRESZCZENIE}

Prezentowane gatunki bezbarwnych euglenin znaleziono na przełomie 1999-2001 roku, na małym, ginącym torfowisku w Budzyniu koło Krakowa (Wyżyna Krakowsko-Częstochowska). Torfowisko położone jest 12 km na północny zachód od centrum Krakowa. Od 1998 roku rozpoczęła się szybko postępująca dewastacja tego terenu. Obecnie tylko na niewielkiej części torfowiska występują rośliny typowe dla torfowisk: Betula sp., Calluna vulgaris L., Carex sp., Drosera rotundifolia L., Eriophorum angustifolium Honck., Lycopodiella inundata L., Lycopodium clavatum L., Oxycoccus quadripetalus Gilib., Pedicularis palustris L., Salix rosmarinifolia L. i Sphagnum spp.

W czasie badań na torfowisku obok glonów należących do różnych grup taksonomicznych znaleziono również 9 gatunków bezbarwnych euglenin należących do rodzajów: Astasia (1 gatunek), Menoidium (3 taksony), Rhabdomonas (2 gatunki), Entosiphon (3 taksony). Trzy z nich Rhabdomonas incurva Fresenius, Entosiphon obliquum Klebs, E. ovatum Stokes i jedna odmiana Menoidium pellucidum Perty var. gracile (Playfair) Popova z Polski podawane są po raz pierwszy. Trzy gatunki Astasia dangeardii Lemmermann var. dangeardii, Rhabdomonas costata (Koršikov) Pringsheim oraz Entosiphon sulcatum (Dujardin) Stein var. sulcatum Stein są nowe dla flory Wyżyny Krakowsko-Częstochowskiej. Pozostałe Menoidium pellucidum Perty var. pellucidum oraz M. tortuosum (Stokes) Senn var. tortuosum są bardzo rzadko podawane z Polski.

SŁOWA KLUCZOWE: Euglenophyta, Astasia, Menoidium, Rhabdomonas, Entosiphon, taksonomia, torfowisko. 